\title{
PRIVATIZATION AND THE ETHICS OF ISLAM
}

\author{
Felix Pomeranz
}

Current privatization efforts dwarf all which have gone before. In general, the "less developed" nations, including peoples of the Muslim faith, seem to have attracted the advocates of privatization. Disturbing results are obtained when the substance and process of privatization are juxtaposed to the teaching of Islam.

In certain cases, privatization may result in the transfer of wealth from relatively weak hands (i.e., from the debtor governments of the less developed nations) to relatively strong hands (i.e., consortia of international entrepreneurs). Islam teaches the opposite: It recognizes the right of the less able in the wealth of those who have greater ability or the opportunity to produce greater wealth (Mirakhor, 1989).

The outcomes of privatization are important to peace and security. Consequently, the emergence of privatization as a cat's paw in political discourse is not a good omen. For example, Abdelhak Benhamouda, Algeria's labor leader, "opposes any privatizations undertaken on the 'back' of the workers and demanded (sic) 'guarantees' from the government" (AFX News, 1995).

The article defines privatization and discusses its structural and operational problems in light of religious imperatives.

\section{Definitions}

Subject to exceptions, there is an important difference in the meaning of the term "privatization" as used in the United States compared to the rest of the world. In most of the world "privatization" is equivalent to denationalization. However, in the U.S. the term typically refers to outsourcing, i.e., the performance of certain tasks by outside contractors.

Felix Pomeranz is Professor and Associate Director of the School of Accounting at Florida International University in Miami and is also affiliated with the Department of Religious Studies. He is a retired partner of Coopers \& Lybrand. 
The distinction between denationalization and outsourcing is basic: outsourcing usually entails neither diminution in public accountability nor change in the interaction of individual citizens with their government; however, denationalization relieves government of further responsibility (Fryklund, 1994).

\section{Reasons for Privatization}

The current rush to privatize is rooted in the widespread belief that state-owned enterprises are inefficient. While there could be merit in this assumption, one might expect that specific programs would be subjected to fact finding before the complex solution of privatization is pursued.

The results of an operational review may support relatively easy solutions such as the outsourcing of specific governmental tasks or the substitution of suppliers where activities are already being outsourced. (The mere act of rebidding could have salutary effects on the performance of an existing supplier.)

\section{Denationalization-Structural Issues}

As mentioned earlier, the tasks which confront denationalizers are enormous. (For example, Egypt's Public Enterprise Office will dispose of $\$ 45$ billion of state assets via commercially-based holding companies.)

Denationalization has long-term effects: once accomplished, denationalization becomes virtually irreversible. Moreover, it is impractical to issue guidance as to the selection of an optimum technique for privatization. The technical difficulties are compounded by a shortage of experienced privatization managers, particularly, persons with the vision required to succeed in culturally diverse situations.

The most important challenge to implementers of privatization is posed by the national ethos of the host nation. Where a choice has been made to denationalize, the model of the process (i.e., its nature, timing, and extent) is greatly influenced by cultural, technological, and social factors.

The ethical awareness of some implementers may differ sharply from that of the hosts. For example, disciples of Milton Friedman, the University of Chicago economist, may have been misguided into viewing profit generation as the basic objective of business. Friedman's views have been decried by ethicists as well as by leaders of business. For example, Margaret Downes, the deputy governor of the Bank of Ireland, has noted that some have described Friedman's views as amoral. In my view, Downes has used the correct adjective.

With respect to a related matter, the U.S. Financial Accounting Standards Board has issued "concept statements" which aver that the objectives of financial reporting are to provide information to "decision 
makers," identified primarily as investors and creditors. Other stakeholders, including regulators, workers, suppliers, members of the community, and taxing authorities, are largely disregarded with respect to their financial information needs. Contrariwise, from an Islamic perspective, U.S. financial reporting could be regarded as substantially irrelevant, because of its preoccupation with two categories of decision makers that are likely to be scarce in developing nations.

Muslims perceive problems with absentee shareholders: Islam obliges business owners to be concerned activists, especially with respect to the welfare of their employees and the preservation of the environment. Islamic theologians tend to be suspicious of stock transactions; they fear that the issuers may have gained some of their profits from interest-based financial deals, contrary to Islamic law. Conservative Muslims may even regard share trading as a form of (prohibited) gambling.

Also, privatization advocates have been known to ignore the employment circumstances of developing nations which may require national, provincial, or municipal governments to serve as employer of last resort. Furthermore, the act of denationalization may incorporate hidden disincentives. For example, it may curtail pre-denationalization public employment which may have brought benefits through policies designed to protect women and minorities.

The operational difficulties of denationalization will be discussed before an attempt is made to reconcile privatization, a free market technique, to Islam.

\section{Denationalization-Operational Difficulties}

Preliminary work is likely to be required before denationalization can commence. This is particularly true where entities have been subject to colonial or other misrule. For instance, in Poland great difficulties have been encountered in making restitution to the victims of communism; in particular, the tracing, discovery, and evaluation of title documents have caused delays and disputes. Similarly, in many states disregard of the environment has made it necessary to formulate policies assigning responsibility for cleaning up current and future damage.

Rarely have the alternatives to denationalization been adequately evaluated. This leads to the following observations: first, denationalization has been applied only to existing enterprises - creation of new ventures has not been addressed; and second, the relatively draconian remedy of denationalization appears to have been favored over lower cost alternatives such as repair, development, absorption, or abandonment.

Some techniques for implementing denationalization (such as sales on the stock market, distribution of vouchers to eligible citizens, transfers to management, etc.) have been dogged by difficulties. For example, preliminary to denationalization it may be necessary to broaden public par- 
ticipation in thin securities markets. Also, both price erosion and price explosion from offering prices have occurred at privatized companies marketed as initial public offerings. (The offering prices should have treated both investors and taxpayers fairly.)

A denationalized entity is subject to normal business risks; however, rarely have these risks been identified, analyzed, or controlled. One such risk, management fraud, represents a particularly dangerous threat. Managers have literally stolen firms; they have sold or leased the assets to shell companies owned by friends or to joint ventures set up with foreign partners, in which they had some kind of stake or guarantee of employment (Gordon, 1994). For instance, in Kuwait alumni of the 1982 collapse of the Souk al-Manakh (which involved violations of religious and secular laws) are said to have been allowed to buy into a denationalized company at bargain prices!

In general, national audit agencies have become involved in denationalization on an ex post facto rather than on a proactive basis; the latter would have tended to make fraud more difficult. In Pakistan the privatization commission itself has become a focus of investigation; it has been reported that its program was well conceived, but that ground rules were not followed ("Pakistan Investment," 1995).

Numerous technical shortcomings have further impeded denationalization. These include absence of a comprehensive strategic plan, unrealistic timetables, inaccurate cost and income projections, inadequate monitoring of progress, and lack of a post-mortem review of the entire process.

The direction of privatization will now be evaluated in light of the teachings of Islam and of Islamic economics (iqtisād).

\section{Some Islamic Basics}

Islam aims to establish a just and moral social order through the agency of man, rooted in justice. Islam does not distinguish between the religious and the secular or between the spiritual and the temporal. Within the framework of Islamic law each person is given freedom of action subject to the limitation that the individual's actions do not violate the rights of others (Mirakhor, 1989). Amr bi al-Ma'ruf wa nahi 'an al-munkar (enjoin the good and forbid the wrong) is the Qur'anic concept that holds the key to the worldview and value system of Islam (Ansar, 1989).

Islam's economic system is an integral part of Islamic life. The expression used for Islamic economics (iqtisād) literally means the "state of being even or equally balanced." Iqtisädi activities are considered to represent a means for showing love of God. ${ }^{1}$ Some differences from Western economics, in terms of emphasis, follow: 
- Westerners may be influenced by materialism; Islam emphasizes eternal values;

- Westerners focus on human laws as governing humanity's wellbeing; Islam sees an omnipotent God;

- Westerners regard resources as limited; Islam sees resources as sufficient (however, it prohibits waste);

- Westerners maintain that wealth can be accumulated; Islam condemns such accumulation while others are in need;

- Westerners regard virtually any activity that leads to profit as lawful; in Islam ethics and humanitarian endeavors play an essential role;

- Westerners allow supply and demand to govern; in Islam there are rules relating to prices and wages;

- Westerners tend to favor private ownership; Islam acknowledges at least three types of ownership, including state ownership (Al-Hasani, 1989).

When some of the rules of Islam and iqtisäd are reviewed in light of the structural and operational issues impacting denationalization, areas of potential friction come into focus:

- The welfare and security of employees;

- The optimum technique for privatization (Islam frowns upon shareholding, but accepts state ownership);

- Ethical awareness on the part of managers and employees; Islam sees the ethics of the righteous individual as governed by both internalized principles and external controls;

- The rights of the various members of the stakeholder family, beyond investors and creditors;

- Environmental protection and the avoidance of waste.

The causes of friction have been presented in realistic terms. Unrest has been mounting over unemployment and ethical issues. In Pakistan, opposition to privatization and pressure from fundamentalists to implement Islamic business practices continue to pose risks. Egyptian labor is strongly opposed to privatization of the state sector, fearing loss of jobs; layoffs following privatization are expected to further increase social tensions. Morocco's biggest union, the Democratic Labor Federation, believes that privatization will cost jobs and further concentrate wealth among the Casablanca-Rabat elite. The Algerian government has called for a "social pact" to soften the flow of the movement toward a market economy. The Speaker of the Kuwait National Assembly has demanded a probe of allegations of insider trading said to have occurred in the State's latest share sale, which has already been alluded to.

\section{Call for Action}

The problems of denationalization must be solved by using a combination of Western and Islamic solutions. The Western solution would 
call for improvement in the denationalization process, including availability of proactive audit support. The Islamic solution would seek to mitigate the effect of structural deficiencies. Time is of the essence.

\section{Notes}

1. Much of the discussion in this section is based on Essays on Iqtisad, Bakir Al-Hasani and Abbas Mirakhor, Editors (Silver Spring, MD: NUR Corp., 1989).

\section{Bibliography}

Al-Hasani, Baqir. "General Characteristics of an Islamic Economic System." In Essays on Iqtisad, Bakir al-Hassáni and Abbas Mirakhor, editors. Silver Spring, MD: NUR Corp., 1989, pp. 21-44.

Anonymous. "At Least a Third of Algeria's Labor Force Unemployed: Algerian Government." AFX News, Section: Company News: Strikes, Wages, May 3, 1995.

Anonymous. "Pakistan Investment: Sell-Off Drive Opens Doors for Foreign Entry." Global Business Markets, April 19, 1995.

Ansar, Syed Jalaluddin. Maroof \& Munkar. Kuwait: Al Faisal Press, 1989.

Downes, Margaret. "Business Ethics: A New World Order." Unpublished speech, Irish Times-Harvard University Colloquium, March 24, 1992.

Fryklund, Inge. "Privatization: American Style." Business Forum 19, nos. 1-1 (January 1994): 495.

Gordon, David. "Privatization in Eastern Europe: The Polish Experience." Law and Policy in International Business 25, no. 2, Special Section: Privatization (January 1994): $517 \mathrm{ff}$.

Mirakhor, Abbas. "General Characteristics of an Islamic Economic System." In Essays on Iqtisad, Baqir al-Hasani and Abbas Mirakhor, editors. Silver Spring, MD: NUR Corp., 1989, pp. 45-80. 